\title{
URLC10-CDCA1-KOC1 Multipeptide Vaccine
}

National Cancer Institute

\section{Source}

National Cancer Institute. URLC10-CDCA1-KOC1 Multipeptide Vaccine. NCI Thesaurus.

Code 195212

A cancer vaccine containing multiple peptide epitopes with potential immunostimulatory and antitumor activities. Peptide epitopes in this vaccine are derived from, URLC10 (upregulated lung cancer 10), CDCA1 (cell division cycle-associated protein 1), KOC1 (IGF II mRNA Binding Protein 3). Upon administration, URLC10-CDCA1-KOC1 multipeptide vaccine may stimulate a cytotoxic T lymphocyte $(C T L)$ response against tumor cells expressing URLC10, CDCA1, KCO1 peptides, resulting in cell lysis and decreased tumor growth. 